\title{
Learning How to Spell in Turkish
}

\section{Ecehan Sönmez, Nalan Babür and Belma Haznedar}

\begin{abstract}
In comparison to the large body of research on reading and its underlying processes in the field of literacy acquisition, the number of studies investigating the components of writing has remained rather limited (Treiman, 1993). Given that spelling is a fundamental aspect of the ability to write, understanding the nature of spelling may contribute to improvements in literacy instruction, in particular, for those who experience learning difficulties. The course of spelling development has been mostly studied in English (Ehri, 1986; Frith, 1980; Gentry, 1982; Henderson, 1985), a language known for its opaque orthography. In recent work there appears to be a growing interest to investigate spelling patterns in relatively transparent orthographies such as German (Wimmer \& Hummer, 1990) and Czech (Caravolas, Volin \& Hulme, 2005). However, only few studies to date have dealt with spelling performance in transparent orthographies such as Finnish (Lehtonen, 2006) and Turkish (e.g., Babayiğit \& Stainthorp, 2007; Erden, Kurdoğlu, \& Uslu, 2002). The primary purpose of the present paper is to examine spelling development in Turkish across grades 1-3. We compared results obtained from different tasks (e.g., single word, sentence and text spelling tasks based on auditory and visual prompts) based on a comprehensive error categorization. Spelling performance in Turkish is analyzed both quantitatively and qualitatively; and the findings are discussed in terms of development of spelling across grades and characteristics of error types according to varying spelling task demands. The most common error type was found to be grapheme substitution, followed by grapheme omission; and auditory prompts yielded more errors when compared to visual prompts, which was an expected outcome. Some implications are made regarding the role of universal processes and language specific characteristics in the emergence of spelling errors.
\end{abstract}

Key Words: Error types, Spelling, Transparent Orthography, Turkish

\section{Introduction}

Literacy acquisition is a long process which sets its ground during the early years of life and continues for years after being shaped by formal literacy instruction at school. The roots of emergent literacy could be traced back to infancy, when babies become exposed to written stimuli on the everyday objects in their environment, and develop some degree of print awareness specific to the orthography of their mother tongue (Lancaster, 2003). This state of readiness is reinforced by the exercises done with the letters in children's names and the alphabet knowledge acquired during the kindergarten years.

Ecehan Sönmez Res. Asst., Boğaziçi University, Faculty of Education, Department of Foreign Language Education,ecehan.sonmez@boun.edu.tr

Nalan Babür,Assist.Prof., Boğaziçi University, Department of Primary Education, Faculty of Education, nalan.babur@boun.edu.tr

Belma Haznedar, Prof., Boğaziçi University, Faculty of Education, Department of Foreign Language Education, haznedab@boun.edu.tr 
Children's sensitivity to sounds and letters developed at this stage facilitates the formal literacy training provided later at school (Treiman, 2006).

Given that literacy is a fundamental asset to communicate, gain access to knowledge and share information, investigating literacy skills is highly important in order to understand developmental, psycholinguistic and cognitive processes underlying reading and writing achievement, and to design more efficient teaching programs not only for normally developing children, but also for those who are faced with learning difficulties.

When compared to the large body of research conducted on reading skills, the number of studies investigating spelling skills is rather limited (Treiman, 1993). The reason for the lack of research in this field is that spelling has long been treated as an epiphenomenal outcome of reading instruction. However, it is recently stated in the literature that spelling is a more complex skill than reading as it involves more complicated and sensitive phonological processes, and there is a need for further spelling research (Babayiğit \& Stainthorp, 2007; Bosman \& Van Orden, 1997; Perfetti, 1997).

While reading, an individual recognizes the letters in a word, matches them with their corresponding sounds and reaches the target word and its meaning by quickly eliminating other possible alternatives in the mental lexicon. While spelling, on the other hand, the cognitive mechanisms work in the opposite direction-the person selects a word from the mental lexicon where the phonological representation of the word is stored along with its meaning, and recalls the graphemes corresponding to the phonemes in that particular word (Perfetti, 1997). Thus, although its strong relationship with reading cannot be underestimated, spelling deserves a more scientific approach as a separate construct. It is predicted that studies dealing with the course of spelling development and its components will provide researchers and educators with a better understanding of psycholinguistic, cognitive and pedagogical aspects of literacy acquisition.

In spelling research, analyzing spelling errors is considered an informative and valuable guideline (Read; 1975, 1986). So far, the majority of studies investigating the developmental patterns of spelling have been conducted in English (Ehri, 1986; Frith, 1980; Gentry, 1982; Henderson, 1985; Treiman, 1993). These studies have focused on the characteristics of spelling errors and revealed that English speaking children go through several stages until they master conventional spelling rules.

Languages demonstrate variation with regard to their writing systems, phonological features and orthographic regularities. Whether a language has a transparent or opaque orthography might influence the course of literacy development (Liberman, Liberman, Mattingly \& Shankweiler 1980). In languages with transparent orthographies, graphemes have one-to-one correspondence with their matching phonemes (Aydin, 2012). While English has a highly opaque orthography, languages such as Finnish or Turkish could be classified as having orthographies with nearly perfect transparency. Hence, it is highly predictable that the patterns of literacy acquisition observed in Turkish will be different from those in English. 
Several studies have found that transparent orthographies facilitate and accelerate reading and spelling development (Durgunoğlu \& Öney, 1999; Lehtonen, 2006; Oktay ve Aktan, 2002; Öney \& Durgunoğlu, 1997; Seymour, Aro ve Erskine, 2003; Wimmer \& Goswami, 1994; Wimmer \& Hummer, 1990). Durgunoğlu and Öney (1999) argue that phonological awareness of Turkish speaking children develop much faster than their English speaking peers, and this factor facilitates the earlier reading achievement among Turkish children. Studies conducted in the relatively transparent orthography of German revealed that German speaking kids performed better on word reading and nonword reading tasks when compared to English speaking children due to their higher levels of phonological awareness (Wimmer \& Goswami, 1994; Wimmer \& Hummer, 1990). In another study comparing English and Czech, Caravolas, Volin and Hulme (2005) found no quantitative differences between the phonological skills which predict the children's spelling skills across languages. However, they stated that literacy acquisition may be dependent on qualitatively different mechanisms in transparent versus opaque orthographies. In another study investigating the spelling of letter doublets in Finnish, Lehtonen (2006) found that Finnish children developed awareness for the letter doublets in their mother tongue well before school instruction, and accounted for this early advantage by the transparent orthography of the Finnish language. The researcher claimed that spelling models developed for opaque orthographies such as English cannot be used in order to explain the developmental processes of spelling in languages such as Finnish.

Findings in the literature highlight the importance of conducting spelling research across languages with different orthographies. To this end, there is need for spelling research in Turkish, which has a special position among other languages with its nearly perfect orthography. Such a study was conducted by Erden, Kurdoğlu and Uslu (2002), who aimed to develop reading and spelling norms to be used in diagnosing learning difficulties among Turkish children. They tested children from $1^{\text {st }}$ to $5^{\text {th }}$ grade and in the spelling section of the study; they used a dictation text consisting of 3 sentences. After the spelling errors made by the children were analyzed and categorized, it was found that the children mostly made punctuation errors and grapheme substitution errors in comparison to other type of spelling errors. They also analyzed the developmental differences across grade levels for each error category and paved a way for the development of standardized spelling tests for Turkish. Future studies with the same purpose will be of high importance since their findings will enhance the quality of teaching methods, material design and curriculum development in Turkish.

The main purpose of the present study is to investigate spelling development across $1^{\text {st }}$, $2^{\text {nd }}$ and $3^{\text {rd }}$ grades of elementary school, and to see how the tests designed using different prompts (auditory versus visual at word, sentence and text levels) will influence the children's spelling performance in Turkish. It also aims to demonstrate the most common error types in spelling based on a comprehensive error categorization, and account for the possible reasons of these errors with regard to universal phonological processes and language specific properties.

\section{Method}




\section{Participants}

79 students attending a state school in Beşiktaş, İstanbul participated in the study. In the sample, there were $241^{\text {st }}$ graders, $272^{\text {nd }}$ graders and $283^{\text {rd }}$ graders. Overall, $46 \%$ of the participants were female students while $54 \%$ consisted of male students. They used cursive writing throughout the data collection process.

\section{Data Collection Instruments}

In the present study, 6 different tests with different modalities and complexities were used in order to assess the spelling skills of Turkish speaking children. The words included in the spelling tests were selected from the passages in the students 'course books.

\section{Word Copying}

In this test, the students were asked to copy 6 words given on a worksheet. Only $1^{\text {st }}$ and $2^{\text {nd }}$ graders took the test. The words were badem (almond), birden (suddenly), bardak (glass), kulübe (cottage), dibinde (at the bottom) and dolabin (of the cupboard), which included several confusing sounds.

\section{Sentence Copying}

The students copied a whole sentence given on the same worksheet. They were supposed to pay attention to the proper use of capital letters and full stop.

\section{Text Copying}

The participants copied a short paragraph given in a separate work sheet.

\section{Word Dictation}

In this test, the researcher read aloud 25 words including several confusing sounds, and the students were asked to spell the words. Each word was read aloud twice.

\section{Text Dictation}

The researcher read aloud short paragraphs whose difficulty was adjusted according to the grade levels. The students were asked to listen and write down the sentences carefully. Each sentence was read aloud twice.

\section{Error Categorization and Scoring}


An extensive error categorization was made in order to classify spelling errors in each test. If a participant spelled the items without any errors, he or she received 1 point in all categories. If the participant made at least 1 specific error type, then he or she received 0 for that category. The error categorization and the examples are demonstrated in Table 1.

Table 1. Error categorization

\begin{tabular}{|l|l|}
\hline Rubric & Error Explanation/Example \\
\hline Writing status & Partial/no writing \\
\hline Legibility & Illegible handwriting \\
\hline Alignment & Writing not aligned well along the line \\
\hline Size & Too small or too big graphemes \\
\hline Syllable separation & Bir-den \\
\hline Syllable addition & Birdenden \\
\hline Syllable omission & Bir \\
\hline Syllable reversal & Denbir \\
\hline Grapheme substitution & Pirden \\
\hline Grapheme addition & Biriden \\
\hline Grapheme omission & Biden \\
\hline Grapheme formation & Improper forms (a, b, e, k, r, g, z)* \\
\hline Dotted graphemes & Birden \\
\hline Dotless graphemes & Külübe \\
\hline Ğ (phonemic representation) & Bairdı, Dooru \\
\hline Title (for texts) & No title \\
\hline Capital letters & Lowercase sentence start \\
\hline Full stop & No full stop at the end of sentences \\
\hline Word omission & Words omitted \\
\hline Word addition & Extra words used \\
\hline Joint word writing & Birrüzgarçiktı \\
\hline Hyphen & Incorrect hyphen use \\
\hline
\end{tabular}




\section{Each grapheme was evaluated separately}

After the scoring procedure, the error frequencies were calculated and percentages were formed out of these frequencies. In addition, the most problematic words were detected in each test, and the common spelling errors made while spelling these difficult words were analyzed by the researcher.

\section{Findings}

\section{Findings across Task Modalities}

As can be seen in Figure 1, when compared to word copying task (with visual prompts), more students made spelling errors in many of the categories in the word dictation task (with auditory prompts). When the students moved from word copying to word dictation, there was an increase in the number of students who made spelling errors in partial writing, grapheme substitution, grapheme omission and grapheme addition categories.

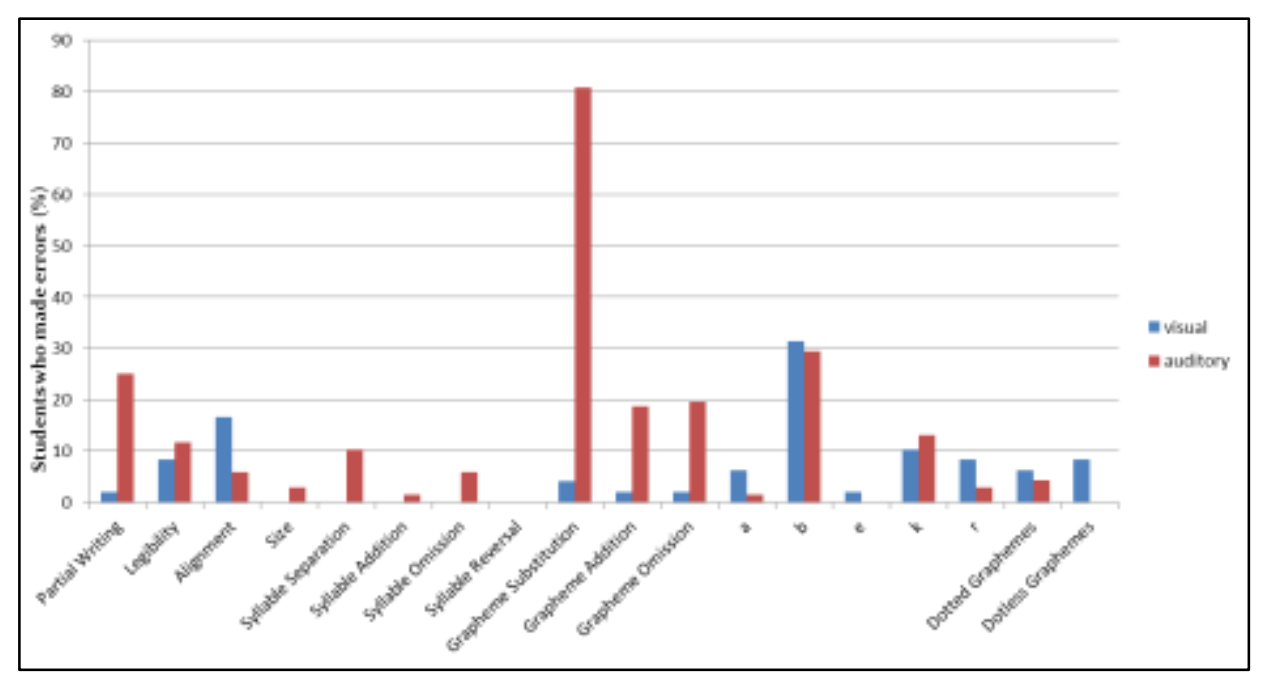

Figure 1. Error Percentages across Word Copying and Word Dictation

When a comparison is made between the spelling performances across text copying and text dictation, a similar pattern is observed (see Figure 2). There was an increase in the number of students who made errors in partial writing, grapheme substitution, grapheme omission, grapheme addition, syllable omission, word omission, use of capital letters, use of full stop, joint writing and use of hyphen during the text dictation task. In other words, text dictation was more difficult than text copying for the students. 
Interestingly, the participants performed better at alignment category in the text dictation task. This situation was probably a result of the different sheets used during the tasks (while the students used a special worksheet for copying, they used a regular notebook sheet for dictation-a material which was more familiar).

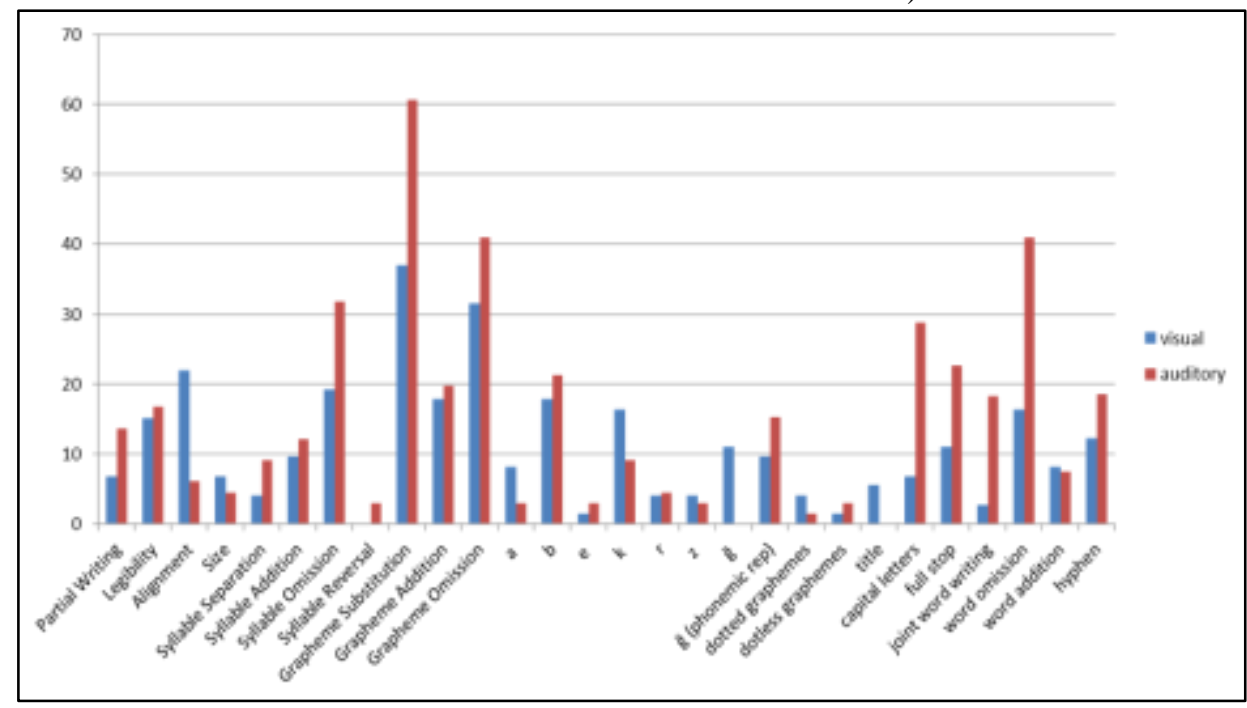

Figure 2. Error Percentages across Text Copying and Text Dictation

Overall, the students seemed to have more difficulty in spelling during dictation tests both at word and text levels. This is an expected outcome since the students had to depend more on their working memory capacities as they were asked to listen and write the words and sentences during the dictation tasks. In addition, as they tried to retrieve correct mappings between the sounds and the letters, the role of phonological awareness and phonological memory came into play, which made the auditory tasks more challenging.

Another finding was that there were more joint writing cases in text dictation in comparison to text copying. This situation shows that the students had problems in differentiating between word boundaries as they listened. This comparison between task modalities supports the argument made by Bosman and Van Orden (1997) who stated that spelling performance might vary to a great extent depending on the test requirements.

\section{Findings across Task Complexities (Lengths)}

As demonstrated by Figure 3, within copying tasks, from word level spelling to sentence and text level spelling, there is an increase in the error percentages in several error categories. 


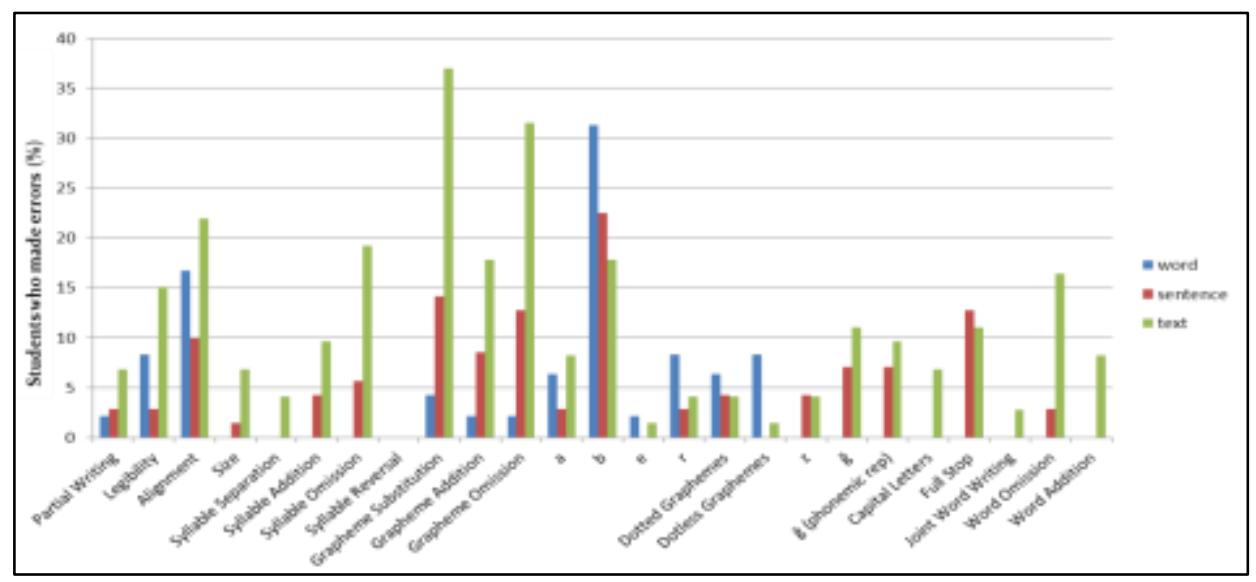

Figure 3. Error Percentages across Word, Sentence and Text Copying

Among the critical error types, the increase in grapheme substitution, grapheme addition and grapheme omission is more salient. This is an expected outcome when the length and the contextual complexity of the text are taken into consideration (Bosman \& Van Orden, 1997).

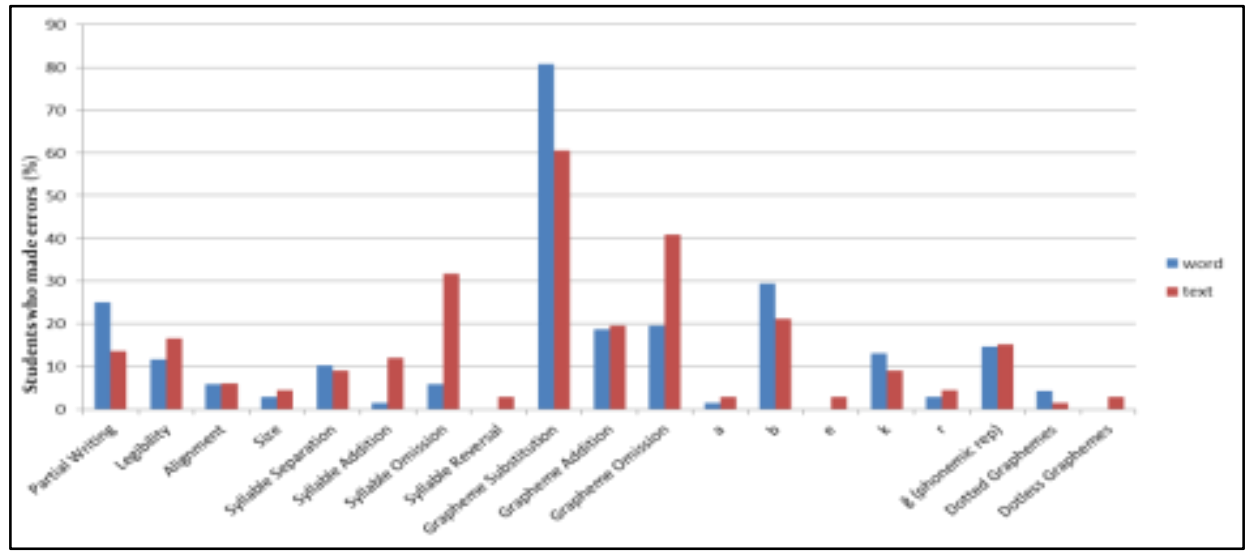

Figure 4. Error Percentages across Word and Text Dictation

In the dictation tasks, the patterns in most of the error categories show parallelism to the findings of the copying tasks. That is, the students had more difficulty in spelling words in a contextual integrity as required by text dictation. Therefore, more students made spelling errors in text dictation than in word dictation, which required spelling of individual words only (see Figure 4). 
Interestingly, the number of the students who did partial writing was higher in word level dictation than in text level dictation. This situation is probably a result of the scoring procedure in which the students received 0 even when they missed one word out of 25 items in the list. Another interesting finding is that more students made grapheme substitution errors in word dictation. The reason for this outcome might be the highly confusing phonemes in words such as pabuç (shoe) and pembe (pink) presented to the children during the word dictation task.

\section{Findings across Grade Levels}

As can be seen in Figure 5, more students from the $1^{\text {st }}$ grade made spelling errors in categories such as partial writing, alignment, legibility, grapheme substitution, grapheme omission, grapheme addition and the formation of the letters $b, k, r$ when compared to $2^{\text {nd }}$ graders in the word copying task. Interestingly, $2^{\text {nd }}$ graders demonstrated poorer performance on the spelling of dotted and dotless graphemes.

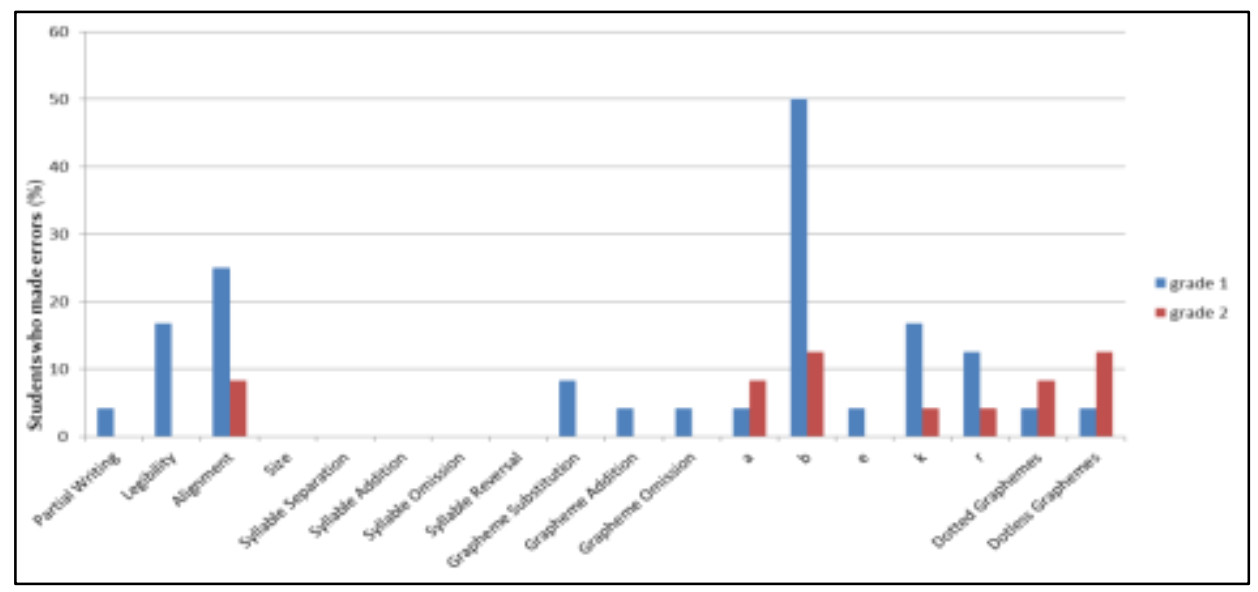

Figure 5. Error Percentages in Word Copying Test across $1^{\text {st }}$ and $2^{\text {nd }}$ grades

In the sentence copying task, there was not a consistent pattern of improvement from $1^{\text {st }}$ to $2^{\text {nd }}$ and $3^{\text {rd }}$ grades (see Figure 6 ). While $1^{\text {st }}$ graders had difficulty in alignment and formation of the letter $b, 2^{\text {nd }}$ and $3^{\text {rd }}$ graders commonly made grapheme substitution and grapheme addition errors. This situation might be a result of the limited number of participants and the distributional characteristics of the sample. 


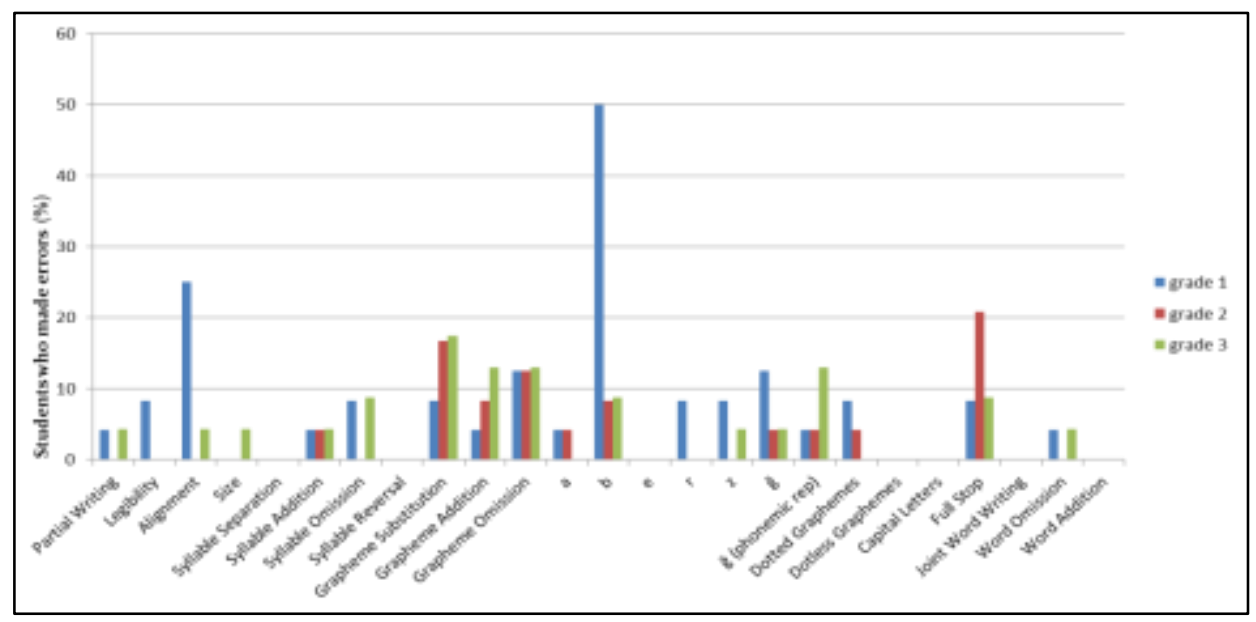

Figure 6. Error Percentages in Sentence Copying across $1^{\text {st }}, 2^{\text {nd }}$ and $3^{\text {rd }}$ grades

In the text copying test, the most salient developmental patterns across grade levels were observed in legibility, grapheme substitution, soft $g$, formation of $k$, joint writing, word omission, word addition and the use of dotted graphemes as presented by Figure 7. The lowest performance in grapheme omission and grapheme addition was demonstrated by $2^{\text {nd }}$ graders in this test.

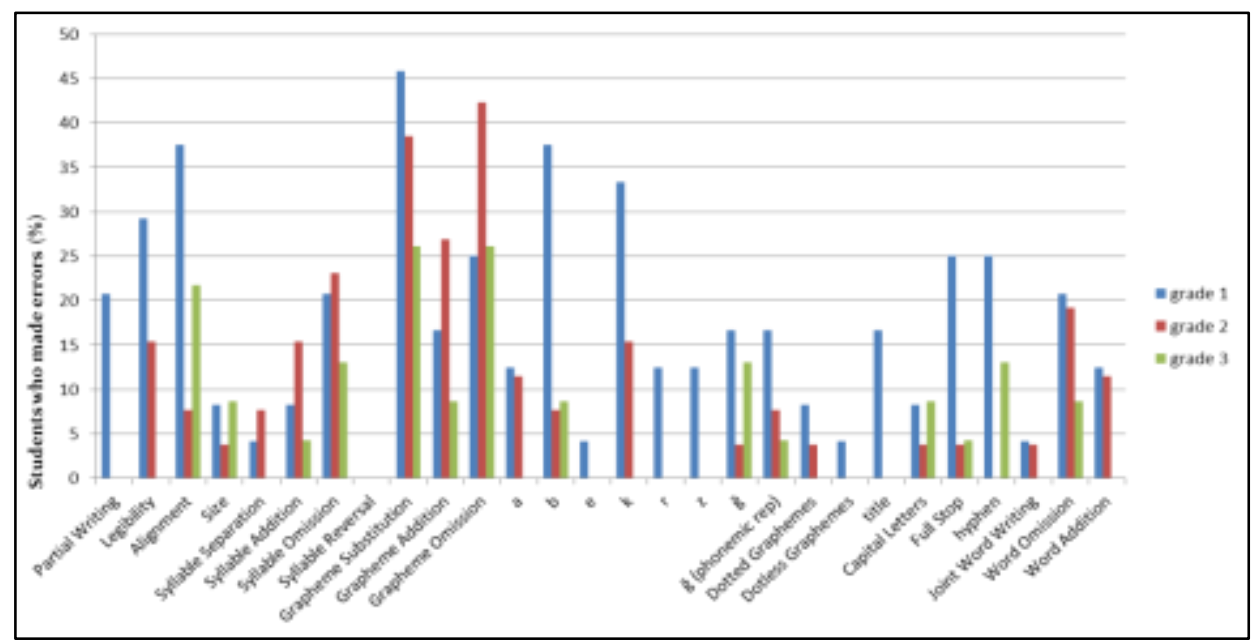

Figure 7. Error Percentages in Text Copying across $1^{\text {st }}, 2^{\text {nd }}$ and $3^{\text {rd }}$ Grades 
In the word dictation test, the developmental patterns across grades were mostly observed in the categories of partial writing, legibility, grapheme substitution, grapheme omission, soft $g$, and formation of $k$. As the grade level increased, the error rates in these categories started to decrease (see Figure 8).

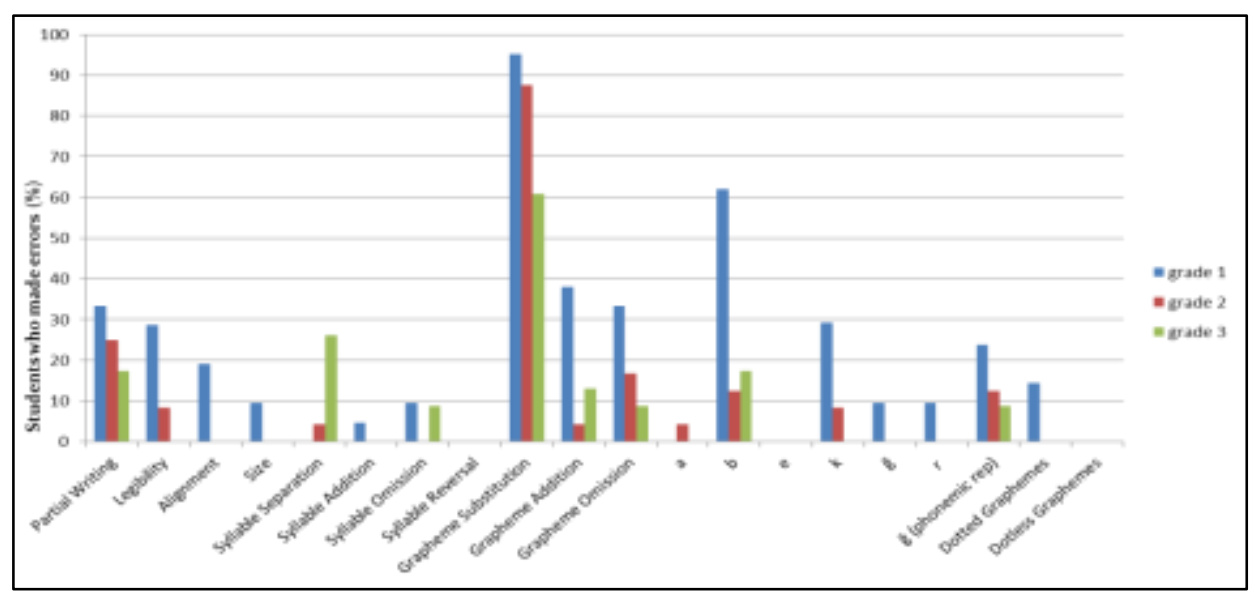

Figure 8. Error Percentages in Word Dictation across $1^{\text {st }}, 2^{\text {nd }}$ and $3^{\text {rd }}$ Grades

The results of the text dictation test are presented in Figure 9. Accordingly, as the grade level increased, the error rates in legibility, grapheme substitution, formation of $b$ and $k$, use of capital letters, hyphen, full stop and word omission tended to decrease.

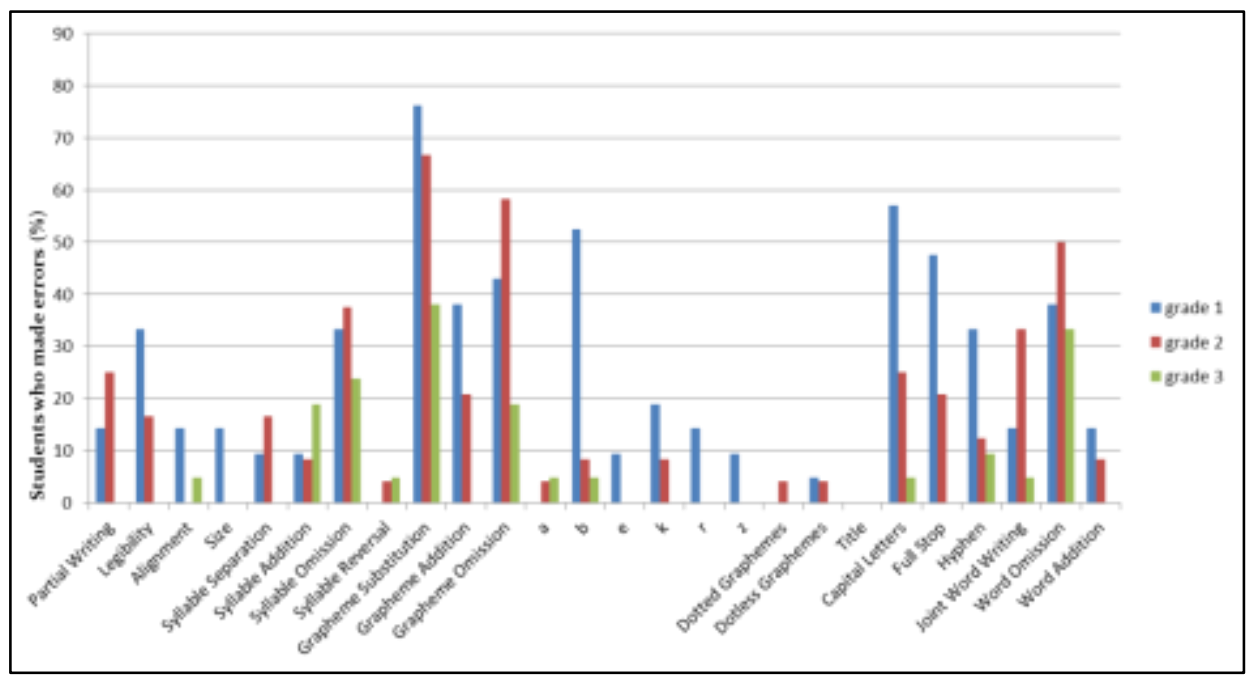

Figure 9. Error Percentages in Text Dictation across $1^{\text {st }}, 2^{\text {nd }}$ and $3^{\text {rd }}$ Grades 
Based on the overall results of the tests, it can be stated that although there is a general improvement in spelling performance across the three grade levels, this improvement is not observed for all of the error categories in all the tests. The existing inconsistencies could be eliminated with a replication of the study with a larger and statistically appropriate sample.

\section{An Analysis of Spelling Errors in relation to Universal Phonological Processes and Language Specific Properties}

In his seminal work, Ingram (1974) investigated the phonological development of English, French and Czech speaking children. According to his findings, regardless of their linguistic backgrounds, children go through similar phonological stages while learning to speak. They tend to choose the easiest and the most economical ways of articulation, and produce utterances by using several operations such as syllable deletion, voicing and sound assimilation.

It is believed that the phonological knowledge children acquire during listening and speaking has an important role not only in the development of reading skills but also in spelling abilities (Bryant, MacLean, Bradley, \& Crossland, 1990). This situation makes it possible to account for a large variety of spelling errors by considering the role of the phonological processes.

In this part of the study, the most problematic words for the participants are presented, and several explanations for the spelling errors are provided with regard to the universal phonological processes and the language specific characteristics of the Turkish language.

In the word copying test, the most problematic word was kulübe (cottage) (21\%). The word was misspelled as külübe $(40 \%)$ or kulube $(30 \%)$ by the majority of the students. Since it is a loan word from Persian, this word violates the palatal harmony (e, $\mathrm{i}, \ddot{\mathrm{o}}, \ddot{\mathrm{u}}$ should be preceded by $e, i, \ddot{o}, \ddot{u}$; and $a, l, o, u$ should be preceded by $a, l, o, u$ ) in Turkish, and the participants' attempt to spell it as külübe might be interpreted as an implicit way of maintaining the palatal harmony of the mother tongue. The reason underlying the other type of misspelling, kulube, seems to be less clear as the children might have simply forgotten to place the diacritics properly.

In the word dictation test, pabuç (shoe) (74\%), dip dibe (nose to tail) (44\%) and kulübe $(39 \%)$ appeared as the most commonly misspelled words. Pabuç was mostly spelled as

papuç (58\%), and dip dibe was spelled as dib dibe (33\%). The effects of universal phonological processes can be observed in these two misspellings. When the students heard the word pabuç, they devoiced $b$ (a voiced consonant) and converted it into $p$ under the influence of the initial $p$ sound. Assimilation of these sounds is frequently applied in spoken Turkish, but it can also occur in other languages. This case is a good example showing that variations in the spoken language may be transferred into written language. Similarly, when spelling dip dibe, the students converted $p$ (voiceless) into $\mathrm{b}$ (voiced) as a result of the preceding sound $d$, which is a voiced consonant. The error types in kulübe were consistent with the ones found in the word copying test (kulube 48 $\%$, külübe $30 \%$ ). Another finding in word dictation was that 3 students from $1^{\text {st }}$ grade (14\%) reversed the graphemes $d$ and $r$ in the proper noun Bodrum, and misspelled the 
word as Bordum. A similar case was observed for the proper noun Bedri, which was misspelled as Berdi by $2(9 \%)$ students from $3^{\text {rd }}$ grade. Furthermore, several instances in which the students made grapheme addition errors while spelling these two words were recorded (i.e. Bodurum, Bediri). Normally, the letters $d$ and $r$ do not follow this sequence in Turkish words. While Bodrum is of Greek origin, Bedri is a borrowed word from Arabic. That might be the reason for the difficulty the children had while trying to spell them. In order to make more detailed explanations for such spelling errors, there is a need for statistical studies investigating the phonotactics (frequencies of phoneme sequences in a syllable or a word) of the words used in Turkish.

In the sentence copying test, many students made errors while spelling the word beğendi (he/she liked it) (20\%). The word was often misspelled as begendi $(57 \%)$ or beyendi $(21 \%)$. This specific example might be indicating the problems faced by the students both in the formation and the phonological conceptualization of soft $\mathrm{g}$, which is an exceptional grapheme violating the regularity between the sounds and the letters in Turkish.

In the text copying test, the students had problems when spelling olacağını (that it will happen) (28\%), birakmamızın (that we release) (24\%) and rüzgar (wind) (18\%). Olacağını was mostly written as olacagını $(35 \%)$ and olacanı $(15 \%)$, a finding which supports the statement that there exist problems regarding soft $g$ among Turkish students. Bırakmamızın is a long and multimorphemic word, and it included many different types of spelling errors. Rüzgar was commonly spelled as ruzgar (30\%) and yüzgar $(23 \%)$. The underlying reason of the misspelling ruzgar might be another attempt to maintain Turkish palatal harmony, or it might be a simple performance error which left the grapheme $\ddot{u}$ dotless. In the misspelling yüzgar, there seems to be the influence of universal phonological processes. This might be an example of liquid gliding in which children substitute /l/ and /r/ with /y/ and /w/, and it occurs in other languages such as English.

In the text dictation test, $1^{\text {st }}$ graders mostly misspelled the words kutbu (pole) (90\%), kutbunda (at the pole) (66\%) and penguenler (penguins) (62\%). The most problematic words for $2^{\text {nd }}$ graders were etmezsek (if we do not do it) $(80 \%$ ) and birakmamaktur (it is not releasing) (54\%). Lastly, $3^{\text {rd }}$ graders had the most difficulty in spelling the word baltallyorlardı (they were axing) (43\%). Kutbu was commonly misspelled as kutubu $(37 \%)$ by $1^{\text {st }}$ graders. The students had difficulty noticing the vowel dropping in the word. Instead of transferring this omission into their spellings, they inserted the grapheme $u$ between $t$ and $b$. This tendency could be explained by the most common syllable type in Turkish, which includes two-letter syllables $(56 \%)$ with a CV structure (51\%) in general (Aşlıyan, Günel, \& Filiz, 2006). This finding reflects the influence of language specific characteristics on the emergence of spelling errors. Kutbunda was frequently spelled as kutpunda (64\%), and accepted as an example of the universal assimilation procedure, in which the participants converted $b$ into $p$ as it was preceded by a voiceless sound, $t$. Penguenler was misspelled as penguvenler (15\%) or penguğenler $(15 \%)$ by the $1^{\text {st }}$ graders. For this specific error, it is predicted that the students inserted additional graphemes between $u$ and $e$ due to the fact that Turkish does not allow vowel doublets. Among $2^{\text {nd }}$ graders, etmezsek was commonly spelled as etmessek $(58 \%)$. This error is another example of assimilation. The sounds /t/, /s/ and 
$/ \mathrm{k} /$ are all voiceless consonants, and the students devoiced the only voiced sound /z/ within this word, and converted it into /s/. This procedure is often observed in the spoken Turkish, as well. However, during the test administration, the researcher paid special attention to the distinction between $\mathrm{z}$ and $\mathrm{s}$. Despite this, findings show that the students did not concentrate on the researcher's pronunciation. Rather, they focused on the phonological representation of the word in their own minds. As another problematic word, birakmamaktır yielded several different types of spelling errors among $2^{\text {nd }}$ graders probably because it is quite a long and multimorphemic word. Lastly, $3^{\text {rd }}$ graders had the most difficulty in spelling the word baltaliyorlardi. Since it is a complex word with several suffixes and the recurring /1/ sound, they misspelled this word in many different ways such as baltall yollard 1 (22\%), baltallyordu (22\%), and baltalı yollardalard $\iota(11 \%)$.

When word omission errors were analyzed, it was found that in the text copying test, the most commonly omitted word was kadar (as) (7\%). In the text dictation test, while $1^{\text {st }}$ graders tended to omit ve (and) $(16 \%), 2^{\text {nd }}$ and $3^{\text {rd }}$ graders mostly omitted bir (a/an) with the rates of $30 \%$ and $14 \%$ respectively. These examples are all function words which do not have deep semantic connections as content words, and it is an understandable finding that they were omitted more frequently by the students.

Error characteristics in this part show that both universal phonological processes and language specific features of Turkish played a major role in the emergence of spelling errors. These factors should be taken into consideration while planning spelling instruction, teacher education and material design.

\section{Discussion}

Overall, the findings of the present study show that the students mostly made grapheme substitution errors and grapheme omission errors. This outcome is in line with the findings of Erden et al. (2002), who found that grapheme substitution errors were more common in comparison to the other type of grapheme errors in their study. Despite the fact that Turkish has a transparent orthography, spelling errors emerge very frequently as a result of the conflict between the spoken variations and the conventional spelling rules in Turkish. This implies that children are in need of more efficient spelling instruction supported by phonological awareness training and conventional spelling requirements.

In all tests, the students mostly had difficulty in the formation of $b$ in cursive writing. This was followed by the letters $k$, $\breve{g}$ and $r$. It seems that teachers should focus on the formation of these particular letters when teaching spelling.

Another important finding is that soft $\mathrm{g}$ may become a problematic grapheme for the students who are learning to spell in Turkish. They make both formation errors and several other types of errors such as grapheme substitution (beyendi instead of beğendi), grapheme addition (eşyağlar instead of eşyalar) and grapheme omission (doru instead of doğru) when they deal with spelling tasks. This finding supports Ergenç's (1991) definition of soft $\mathrm{g}$ as an exceptional phenomenon which causes vowel lengthening and vowel shift in Turkish. Therefore, special activities regarding the case of soft $\mathrm{g}$ should be included or reinforced in the literacy curriculum at schools. 
When the tests were compared in terms of different modalities, it was found that more students made spelling errors in the tests which used auditory prompts than in the ones which used visual prompts. This finding was explained by the working memory and phonological memory demands of the dictation tasks.

When the tests were compared based on their complexities (length), the students were found to have more difficulty when spelling words in a contextual integrity than when spelling them individually. These results demonstrate that spelling performance show variation depending on the task type and task requirements.

Across grades, an improvement was detected in many of the error categories in many of the tests. In general, it can be argued that as the grade level increased, the spelling performance improved among the children. This situation was not valid for all the error types in all the tests. Therefore, more evidence provided by similar studies with larger and statistically more appropriate samples seems necessary to see a clearer picture of the characteristics of spelling development in Turkish.

This study shows that children transfer phonological variations in spoken Turkish to their spellings, and it points to the complex relationships between phonological components of spoken and written language. In addition to the phonological and orthographic rules of Turkish, universal phonological processes also play a role in the emergence of spelling errors.

\section{Conclusion}

This study aims to understand the underlying processes of spelling in Turkish, explain the developmental course of spelling, and discuss the possible reasons of spelling errors. It is expected that it provides some insight into the most common error types in Turkish spelling and leads to further research in order to find more efficient solutions to the problems of literacy training at schools. 


\section{References}

Aşliyan, R., Günel, K., \& Filiz, A. (2006). Türkçe Otomatik Heceleme Sistemi ve Hece İstatistikleri, Akademik Bilişim + BilgiTek IV Konferansı, Pamukkale Üniversitesi, Denizli.

Aydın, Ö. (2012). Elifbâdan alfabeye: İki yazı sisteminde yazıbirim-sesbirim etkileşimi. ODTÜ Gelişme Dergisi, 39, 61-86.

Babayigit, S. \& Stainthorp, R. (2007). Preliterate phonological awareness and early literacy skills: Evidence from Turkish. Journal of Research in Reading, 30, 394-413.

Bosman, A. M. T. \& Van Orden, G. C.(1997). Why spelling is more difficult than reading. In C. A. Perfetti, L.Rieben ve M. Fayol, (Eds.), Learning to spell: Research, theory, and practice across languages (pp. 173-194). Hillsdale, NJ: Lawrence Erlbaum Associates.

Bryant, P.E., MacLean, M., Bradley, L.L. \& Crossland, J. (1990). Rhyme and alliteration, phoneme detection, and learning to read. Developmental Psychology, 26, 429-438.

Caravolas, M., Volin, J. \& Hulme, C. (2005). Phoneme awareness is a key component of alphabetic literacy skills in consistent and inconsistent orthographies: Evidence from Czech and English children. Journal of Experimental Child Psychology, 92(2), 107-139.

Durgunoglu, A.Y.\& Öney, B. (1999). A cross-linguistic comparison of phonological awareness and word recognition. Reading \& Writing, 11, 281-299.

Ehri, L. C. (1986). Sources of difficulty in learning to spell and read. Advances in developmental and behavioral pediatrics, 7, 121-195.

Erden G., Kurdoğlu F. \& Uslu, R. (2002). İlköğretim okullarına devam eden Türk çocuklarının sınıf düzeylerine göre okuma hızı ve yazım hataları normlarının geliştirilmesi. Türk Psikiyatri Dergisi, 13(1), 5-14.

Ergenç, İ. (1991). < $\breve{\mathrm{g}}>$ üzerine. In A. Sezer, A. ve S. Koç, (Eds.), Dilbilim Yazıları (pp. 51-56). Usem Yayınları, Ankara,

Frith, U. (1980). Unexpected spelling problems. In U. Frith (Ed.), Cognitive processes in spelling (pp. 495-516). London: Academic Press.

Gentry, J.R. (1982). An analysis of developmental spelling in GNYS AT

WRK. The Reading Teacher, 36, 192-200.

Henderson, E. (1985). Teaching spelling. Boston: Houghton Mifflin.

Ingram, D. (1974). Phonological Rules in Young Children. Journal of Child

Language, 1, 49-64

Lancaster, L. (2003). Moving into Literacy: How it all begins. In R. M. Joshi ve P. G. Aaron (Eds.), Handbook of orthography and literacy (pp. 145-153). Mahwah, NJ: Erlbaum.

Lehtonen, A. (2006). The sources of information children use in learning to spell: The case of Finnish geminates. In R. M. Joshi ve P. G. Aaron (Eds.), Handbook of orthography and literacy (pp. 63-79). Mahwah, NJ: Erlbaum.

Liberman, I., Liberman, A.M., Mattingly, I. \& Shankweiler, D. (1980). Orthography and the Beginning Reader. In J.F. Kavanagh ve R.L. Venezky 
(Eds.) Orthography, Reading, and Dyslexia (pp. 137-153).University Park Press: Baltimore.

Oktay, A. \& Aktan, K. E. (2002). A Cross-linguistic Comparison of Phonological Awareness and Word Recognition in Turkish and English. International Journal of Early Years Education, 10(1), 37-48.

Öney, B. \&Durgunoglu, A.Y. (1997). Beginning to read in Turkish: A phonologically transparent orthography. Applied Psycholinguistics, 18, 1-15.

Perfetti, C. A. (1997). The psycholinguistics of spelling and reading. In C. A.Perfetti, L. Rieben, \& M. Fayol (Eds.), Learning to spell: Research, theory, and practice across languages (pp.21-38). Mahwah, NJ: Erlbaum.

Read, C. (1975). Children's categorization of speech sounds in English. Urbana, IL: National Council of Teachers of English.

Read, C. (1986). Children's creative spelling. London: Routledge \& Kegan Paul.

Seymour, P.H.K., Aro, M., ve Erskine, J.M. (2003). Foundation literacy acquisition in European orthographies. British Journal of Psychology, 94, 143-174.

Treiman, R. (1993). Beginning to spell: A study of first-grade children. New

York: Oxford University Press.

Treiman, R. (2006). Knowledge about letters as a foundation for reading and spelling. In R. M. Joshi ve P. G. Aaron (Eds.), Handbook of orthography and literacy (pp. 581-599). Mahwah, NJ: Erlbaum.

Wimmer, H. \& Goswami, U. (1994). The influence of orthographic consistency on reading development: Word recognition in English and German children. Cognition, 51, 91-103.

Wimmer, H. \& Hummer, P. (1990). How German speaking first graders read and spell: Doubts on the importance of the logographic stage. Applied Psycholinguistics, 11, 349-368.

\title{
Türkçe’de Yazma Becerisinin Gelișimi
}

\begin{abstract}
Özet
Okuma süreçleri üzerine yapılan çok sayıda çalıșmaya oranla, yazma becerisini araștıran çalıșmaların sayıs oldukça sınırlıdır (Treiman, 1993). Yazma becerisinin doğasını ve altında yatan bilişsel süreçleri anlamak, okuma yazma öğretimindeki gelișmelere katkıda bulunmak ve öğrenme güçlüğü yașayan öğrencilerin ihtiyaçlarına yönelik programlar geliştirmek açısından son derece önemlidir. Yazmanın gelişimsel seyri, genellikle Ingilizce gibi saydam olmayan dillerde araştırılmıştır (örn. Ehri, 1986; Frith, 1980; Gentry, 1982; Henderson, 1985). Günümüzde, yazma süreçleri Almanca (örn. Almanca (Wimmer \& Hummer, 1990) ve Çekçe (Caravolas, Volin \& Hulme, 2005) gibi daha saydam dillerde de araştırllmaya başlamiştır. Öte yandan, Fince (Lehtonen, 2006) ve Türkçe (Babayigit \& Stainthorp, 2007; Erden, Kurdoğlu, \& Uslu, 2002) gibi tamamen saydam dillerde yürütülen çalışma sayısı oldukça azdır. Bu çalışmanın temel amacı, Türkçedeki yazma becerisini ilkokul 1-3. sinıflar arasında gelişimsel olarak incelemektir. Farkl uyaranların kullanıldı testler (ișitsel ve görsel uyaranlara göre sözcük, tümce ve metin yazma) İstanbul'un Beșiktaş ilçesindeki bir okulda ögrenim gören 79 ilkokul ögrencisine uygulanmış ve elde edilen veri, detaylı bir hata sinıflandırması kapsamında nitel ve nicel olarak analiz edilmistir. Bulgular, sinıflar arası gelișimsel farklar ve test türüne göre değişen hata türleri açısından tartışılmıştır. En yaygın hata türü harf karıştırma ve harf atlama olarak belirlenmiş ve işitsel uyaranların görsel uyaranlara kıyasla daha fazla sayıda hataya yol açtığ gözlemlenmiștir. Ayrıca, yazım hatalarının oluşumunda evrensel süreçlerin ve dile özgü unsurların rolü karşılaştırmalı olarak incelenmiştir.

Anahtar sözcükler: Yazma, Türkçe, Saydam Yazı Sistemi, Hata Türleri
\end{abstract}

